\title{
EFEKTIVITAS METODE PEMBELAJARAN PENDIDIKAN AGAMA ISLAM GUNA PENINGKATAN PEMAHAMAN PADA ANAK TUNA GRAHITA SLB NEGERI KOTA METRO
}

\author{
Oleh. \\ Nina Tisnawati \& Ade Aulia Rahman \\ Universitas Muhammadiyah Metro \\ ninaumiufaira@gmail.com \& adealfashi38@gmail.com
}

\begin{abstract}
Islamic Religion Teachers are supervisors, therefore in the teaching and learning process there needs to be methods in accordance with their students. In learning Islamic Religion various methods were developed in educating students, educating mentally disabled children needed methods that are used specifically in each learning process, the problem we will discuss is how the effectiveness of the implementation of Islamic Education teacher teaching methods in the learning process in children mentally disabled people are at the Metro South State Metro School. The focus of research on the effectiveness of the implementation of Islamic Education teacher teaching methods in the teaching and learning process for mentally disabled children is at the Metro South State Metro School. The limitation of this problem is that in this study we will discuss the effectiveness of the implementation of Islamic Education teacher teaching methods in the teaching and learning process for mentally disabled children at the Metro South State Metro School. The purpose of this study was to determine the effectiveness of the teaching methods of teaching Islamic Education teachers in the teaching and learning process for mentally disabled children at the Metro South State Metro School. in developing various methods in the teaching and learning process, while practically this research can provide input for Islamic education teachers at the Special Schools in the Southern City of Metro in effective learning. The method used in this study is an unstructured interview method, then the researcher uses unstructured observation methods. what the research did in this case was to observe directly the teaching and learning process in the classroom and outside the classroom, another method that researchers used was the method of documentation as a support in this study.
\end{abstract}

Keywords: Learning Methods, Middle Ages 


\begin{abstract}
Abstrak
Guru Agama Islam adalah sebagai pembimbing, maka dari itu dalam proses belajar mengajar perlu adanya metode-metode yang sesuai dengan anak didiknya. Dalam pembelajaran Agama Islam dikembangkan berbagai metode dalam mendidik anak didik, mendidik anak tuna grahita di perlukan metode yang di gunakan secara khusus dalam setiap proses pembelajaran, masalah yang akan kita bahas adalah bagaimana efektivitas pelaksanaan metode mengajar guru Pendidikan Agama Islam dalam proses belajar mengajar pada anak tuna grahita sedang di Sekolah Luar Biasa Negeri Metro Selatan Kota Metro. Fokus penelitian pada efektivitas pelaksanaan metode mengajar guru Pendidikan Agama Islam dalam proses belajar mengajar pada anak tuna grahita sedang di Sekolah Luar Biasa Negeri Metro Selatan Kota Metro. Pembatasan masalah ini bahwa dalam penelitian ini akan membahas mengenai efektivitas pelaksanaan metode mengajar guru Pendidikan Agama Islam dalam proses belajar mengajar pada anak tuna grahita sedang di Sekolah Luar Biasa Negeri Metro Selatan Kota Metro. Tujuan penelitian ini untuk mengetahui efektivitas pelaksanaan metode mengajar mengajar guru Pendidikan Agama Islam dalam proses belajar mengajar pada anak tuna grahita sedang di Sekolah Luar Biasa Negeri Metro Selatan Kota Metro. dalam mengembangkan berbagai metode dalam proses belajar mengajar, sedangkan secara praktis penelitian ini dapat memberikan masukan bagi guru pendidikan Agama Islam di Sekolah Luar Biasa Negeri selatan Kota Metro dalam pembelajaran yang efektif. Metode yang digunakan dalam penelitian ini adalah metode wawancara tidak berstruktur, selanjutnya peneliti gunakan metode observasi tidak berstruktur. yang penelitian lakukan dalam hal ini adalah mengamati secara langsung proses belajar mengajar di dalam kelas maupun di luar kelas, metode lain yang peneliti gunakan adalah metode dokumentasi sebagai pendukung dalam penelitian ini.
\end{abstract}

\title{
Kata Kunci: Metode Pembelajaran, Tuna Grahita
}

\section{A. PENDAHULUAN}

Permasalahan yang dihadapi anak tuna grahita sedang kelas IX SMPLB/C dalam pembelajaran PAI, diantaranya yaitu (1) rendahnya motifasi dan minat siswa dalam mengikuti pembelajaran pendidikan Agama Islam (PAI), (2) kurangnya perhatian siswa terhadap materi yang disampaikan guru, (3) siswa merasa cepat bosan danjenuh di kelas, dan (4) rendahnya pemahaman siswa terhadap materi pelajaran PAI, (5) dan terutama adalah kesulitan mereka memahami sesuatu hal yang bersifat abstrak dengan begitu hal tersebut dapat berpengaruh terhadap prestasi belajr siswa. ${ }^{1}$

Keterhambatan perkembangan intelegensi anak tuna grahita ringan memberi dampak negatif terhadap kemampuan bernalar mereka. Di samping itu daya ingat mereka juga $\begin{array}{cc}1 \text { Ibu Umi } & \text { Sarimanah, } \\ \text { Wawancara, Senin, } 10 & \text { Oktober 2016 }\end{array}$ 
lemah sehingga mereka mengalami kesulitan dalam berfikir abstrak. ${ }^{2}$

Setiap individu yang menyandang kelainan, khususnya tuna grahita, membutuhkan yang namanya pelayanan pendidikan secara khusus dan intensif yang disesuaikan dengan objeknya. Anak tuna grahita adalah mereka yang kecerdasannya jelas di bawah anak ratarata pada umumnya. Di samping itu mereka mengalami keterbelakangan dalam menyesuaikan diri dengan lingkungan, mereka kurang cakap dalam memikirkan hal-hal yang abstrak yang sulit dan berbelit-belit. ${ }^{3}$

Menurut ibu Sari Manah selaku guru pendidikan Agama Islam "Anak tuna grahita banyak macamnya, ada yang disertai dengan buta mata, buta warna, desertai dengan postur tubuh yang kecil (kerdil), disertai dengan kepala panjang, disertai dengan bau tertentu, dan sebagainya, akan tetapi ada pula yang tidak disertai apa-apa layaknya sebagimana anak normal". 4

Sehubungan dengan itu, dalam mencapai tujuan pendidikan khususnya dalam kegiatan belajar mengajar, seorang pendidik harus berperan aktif dalam kegiatan tersebut. Dalam kegiatan belajar mengajar salah satu tugas guru adalah mengajar, maksudnya menyampaikan pelajaran kepada anak didik agar anak didik tersebut memperoleh kecakapan dan pengetahuan serta dapat

\footnotetext{
${ }^{2}$ Ibid

3 Ibu Asri, wali kelas IX tuna grahita, Wawancara, Senin 27 Oktober 2016

${ }^{4}$ Ibu Umi Sarimanah, Op. Cit
}

mengembangkan pribadinya melalui proses belajar mengajar.

Setiap saat dalam mengajar, guru harus mampu menerapkan dan memilih mana diantara metode-metode mengajar yang dapat dan cocok diterapkan atau digunakan, dengan mempertimbangkan dari berbagai kemungkinan dan faktor mengenai kewajaran metode tertentu, dan situasi khusus yang dihadapi, sebab dengan metode mengajar tersebut guru dapat meletakkan garis-garis benar menentukan jalannya pembelajaran.

Metode adalah rencana menyeluruh tentang penyajian materi ajar secara sistematis dan berdasarkan pendekatan yang ditentukan. Jadi metode merupakan cara yang di dalam fungsinya merupakan alat untuk mencapai suatu tujuan.

Namun perlu juga untuk diingat dalam pemakaian metode tersebut, guru tidak mesti mengikuti metode-metode tertentu secara rutin akan tetapi boleh mengkombinasikan berbagai metode yang satu dengan yang lain yang saling mendukung, jadi mungkin dua metode, tiga metode, empat metode atau bahkan lima metode, yang dipakai dalam satu kali dalam berlangsungnya proses pembelajaran, terlebih lagi pada anak tuna grahita.

Proses pembelajaran yang
didalamnya meliputi banyak hal
diantaranya yaitu bagaimana pelaksanaan
mengajar guru menyampaikan materi
pelajaran kepada siswa dan metode apa
saja yang harus digunakan sehingga akan
berlangsung proses belajar mengajar


yang sesuai dengan apa yang telah direncanakan.

Di dalam proses belajar mengajar seorang guru hendaknya tidak menggunakan hanya satu metode saja, karena dengan menggunakan satu metode siswa akan merasa bosan dan siswa tidak tertarik dengan materi yang akan disampaikan.

Untuk mencapai tujuan agar siswa dapat berhasil dalam belajar hendaknya guru perlu menggunakan metode bervariasi, karena dengan menggunakan metode bervariasi dapat meningkatkan kegiatan belajar siswa, selain itu menentukan berhasil atau tidaknya suatu tujuan yang akan dicapai tergantung pada penggunaan metode yang tepat akan menghasilkan pemahaman yang baik dan pada akhirnya akan dapat mengamalkan dengan baik pula.

Dalam pelajaran Pendidikan Agama Islam, guru atau pendidik harus memberikan metode yang sesuai dengan keadaan anak didik tersebut. Tidak mudah untuk mengajar peserta didik terutama pada anak cacat mental (tuna grahita) yang merupakan anak mempunyai kelainan atau hambatan dalam perkembangan mental intelektual atau secara umum keterhambatan dalam fungsi kecerdasaan memerlukan metode khusus dan seorang guru harus menghadapi hambatan-hambatan yang harus dihadapi oleh seorang guru, karena membutuhkan bimbingan yang ekstra dalam proses belajar mengajar

Dari penjabaran latar belakang di atas maka penelitian ini dalpat di rumuskan: 1). Bagaimana efektivitas pelaksanaan metode pembelajaran pendidikan Agama Islam guna peningkatan pemahaman pada anak tuna grahita sedang kelas IX SMPLB/C di Sekolah Luar Biasa Negeri Metro. Bagaimana hasil pelaksanaan metode pembelajaran pendidikan Agama Islam pada anak SMP tuna grahita sedang kelas IX SMPLB/C di Sekolah Luar Biasa Negeri Metro

Tujuan penelitian adalah, 1) Untuk mengetahui pelaksanaan metode mengajar guru pendidikan Agama Islam pada anak tuna gharita di sekolah Luar Biasa Negeri Metro. 2).Untuk memberikan motivasi terhadap guru Agama Islam dalam meningkatkan pelaksanaan metode mengajar pada anak tuna gharita di Sekolah Luar Biasa Negeri Metro.

Metode penelitian ini penulis mengumpulkan data melalui riset lapangan, ditambah dengan riset perpustakaan yang dikumpulkan dari berbagai sumber. Adapun pendekatan penelitian yang penulis lakukan ini bersifat kualitatif. Yaitu dengan guru pendidikan Agama Islam menjadi sumber utamanya dan guru kelas, adapun faktor pendukung yaitu dari pihak kepala sekolah dan peserta didik. Penelitian ini menggunakan penelitian lapangan, dengan model penelitian kualitatif.

Penelitian ini dilakukan di Sekolah Luar Biasa Negeri Metro Jl. Gatot Kaca, desa Sumber Sari Bantul Kecamatan Metro Selatan Kota Metro. Sumber data yang diperoleh dari penulisan ini didapat dari beberapa informan, antara lain Kepala Sekolah SLB, waka kurikulum, 
staf tata usaha, guru kelas, dan guru mata pelajaran pendidikan Agama Islam

\section{B. PEMBAHASAN}

\section{Pengertian efektif}

Kata efektif yang kita pakai di Indonesia merupakan persamaan kata dari bahasa Inggris yaitu dari kata "effective", arti dari kata ini yaitu berhasil atau sesuatu yang dilakukan berhasil dengan baik. Sedangkan dalam Kamus Besar Bahasa Indonesia, kata efektifitas mempunyai beberapa pengertian yaitu, akibatnya, pengaruh dan kesan, manjur, dapat membawa hasil. ${ }^{5}$ Dalam kamus Ilmiah Populer, efektivitas adalah ketepat gunaan, hasil guna, menunjang tujuan. ${ }^{6}$

Menurut Yusufhadi Miarso, efektivitas pembelajaran adalah yang menghasilkan belajar yang bermanfaat dan bertujuan bagi paramahasiswa melalui prosedur pembelajaran yang tepat. ${ }^{7}$ Menurut Miarso, efektivitas adalah usaha pembelajaran yang berkriteria daya tarik atau daya guna, artinya dengan pemanfaatan seperangkat karakteristik yang tersembunyi guru menolong siswa mencapai tujuan pembelajaran. Dengan kata lain efektivitas adalah salah satu indikator dari proses pembelajaran yang baik,

5 Tim Penyusun Kamus Besar Bahasa Indonesia , Jakarta: Balai Pustaka, 1995, h. 284

6 Widodo dkk, Kamus Ilmiah Populer Dilengkapi EYD Dan Pembentukan Istilah, Yogyakarta: Absolut, 2002, h. 114

${ }^{7}$ Yusufhadi Miarso, Menyemai Benih Teknologi Pendidikan, Jakarta: Pramadah Media, 2004, h. 536 sedangkan indikatornya adalah efisien dan produktifitas. Menurut Miarso, produktivitas pembelajaran adalah hasil yaitu, karya tulis, penelitian dan sebagainya, bertambah dengan pengurangan masukan, atau pertambahan masukan atau tanpa penambahan masukan, atau dengan tambahan masukan sedikit tetapi pertambahan hasil lebih besar, atau pertambahan masukan yang banyak dengan hasil yang jauh lebih banyak. Sedangkan efesiensi pembelajaran adalah kesamaan antara waktu, biaya, dan tenaga yang digunakan dengan hasil yang diperoleh. ${ }^{8}$

Dari pengertian-pengertian di atas dapat disimpulkan efektivitas adalah suatu ukuran yang menyatakan seberapa jauh target (kualitas, kuantitas dan waktu) yang dicapai oleh manajemen, yang mana target tersebut sudah ditentukan terlebih dahulu.

\section{Ciri-ciri Efektivitas}

Ciri-ciri evektivitas seorang guru dalam mengajar meliputi beberapa hal sebagai berikut:

a. Tujuan yang hendak dicapai itu harus tepat kepada sasaran

b. Penerapan penggunaan media dan metode harus dilakukan secara berulang-ulang.

c. Bahan pelajaran yang akan disampaikan harus dikuasai sebaik mungkin.

d. Menggunakan media yang tepat dan bervariasi.

\footnotetext{
${ }^{8}$ Ibid, h. 517
} 
e. Dapat menimbulkan semangat siswa untuk belajar dan membimbing anak agar memiliki daya kreasi dan bekerja. ${ }^{9}$

\section{Pengertian Metode Pembelajaran}

Metode dalam bahasa Arab dikenal sebagai istilah Thoriqoh yang berati langkah-langkah yang dipersiapkan untuk melakukan suatu pekerjaan. Metode ini harus diwujudkan dalam proses pembelajaran dalam rangka pengembangan sikap keperibadian peserta didik. ${ }^{10}$

Secara bahasa metode berasal dari bahasa Yunani yaitu Methodos. Kata ini berasal dari dua suku kata yaitu Metha yang berarti melewati atau melalui dan hados yang berati jalan atau cara. ${ }^{11}$ Secara istilah metode dapat dimaknai sebagai jalan yang ditempuh oleh seseorang supaya sampai pada tujuan tertentu, baik dalam lingkungan atau perniagaan maupun dalam kaitan ilmu pengetahuan. $^{12}$

Metode yang digunakan dalam pembelajaranpun tidak akan sama tergantung dengan situasi dan kondisi, dan dalam arti yang sesungguhnya, maka maka Merber (yunani:metodhes) adalah cara atau jalan. Sehubungan dengan karya ilmiah, maka metode menyangkut

\footnotetext{
${ }^{9}$ Roestiyah NK, Didaktik Metodik, Jakarta: Bina Aksara, 1982, h. 4

10 Ramayulis, Metodologi Pendidika, Jakarta: Bumi Aksara, 2002, h. 3

11 Akmal Hawi, Kompetensi Guru Pendidikan Agama Islam, Jakarta: PT. Raja Grafindo Persada, 2013, h. 27

12 Ahmad Sarbi, Strategi Belajar Mengajar Micro Teaching, Jakarta: Quantum Teaching, 2005, h. 52-53
}

dengan masalah kerja, yaitu cara kerja untuk memahami objek yang menjadi sasaran ilmu yang bersangkutan. ${ }^{13}$

Sistem mengajar membutuhkan metode atau cara dalam setiap pembelajaran agar setiap peserta didik tidak merasa bosan atau jenuh dalam proses belajar mengajar, dan harus memiliki teknik untuk penyampaianpenyampaian baru disetiap pertemuan.

Setiap yang diungkapkan Zakiah Darajat, metode mengajar itu adalah suatu teknik penyampaian baru pelajaran kepada murid. ${ }^{14}$ Sedangkan metode mengajar menurut M. Basyirudin Usman 'metode mengajar ialah alat yang merupakan perangkat atau bagian dari suatu strategi pengajaran. ${ }^{15}$

Dari pengertian di atas dapat disimpulkan bahwa metode mengajar adalah cara atau teknik penyampaian atau strategi dalam proses belajar mengajar yang diberikan kepada anak didik.

Sehubungan dengan itu, di Indonesia saat ini menggunakan kurikulum SLB bagian C tahun 1984 yang telah dilakukan dengan surat keputusan Menteri Pendidikan dan Kebudayaan dan metode yang dipakai untuk anak-anak tuna grahita adalah: Metode ceramah, Metode tanya jawab,

13 Koentjaraningrat, Metode-metode penelitian masyarakat, Jakarta: PT.Gramedia, 1986, h. 7

14 Zakiah Daradjt dkk, Metodologi Pengajaran Agama Islam, Jakarta: Bumi Aksara, 1996, h. 61

15 M. Basyirudin Usman, Metodologi pembelajaran Agama Islam, Jakarta: Ciputat Pers, 2002, h. 22 
Metode demonstrasi, Metode karyawisata, Metode dramatisari, Metode sosio-drama, Metode pemberian tugas (resitasi) dan Metode eksperimen ${ }^{16}$

Demikian yang diungkapkan oleh Soebrata tentang strategi pembelajaran PLB adalah sebagi berikut: Metode ceramah, Metode tanya jawab, Metode diskusi, Metode demonstrasi, Metode tugas/resitasi, Metode kerja kelompok, Metode pengalaman lapangan, Metode drill/latihan siap dan Metode sosio drama $^{17}$

\section{Faktor-faktor yang Mempengarui Penetapan Metode}

Memilih metode harus disesuaikan dengan mata pelajaran yang akan disampaikan, karena semua metode apa saja dapat dilakukan untuk tercapainya tujuan pendidikan sebab metode itu tidak ada yang jelek dan yang baik, semua itu tergantung pada banyak faktor. Berikut beberapa faktor yang mempengarui atau yang harus diperhatikan dalam penetapan metode yang akan digunakan sebagai alat dan cara dalam penyajian bahan pengajaran, yaitu:

a. Tujuan Instruksional Khusus. Tujuan instruksional khusus merupakan unsur utama yang harus dikaji dalam rangka menetapkan metode. Caracara atau metode-metode yang hendak digunakan itu harus disesuaikan dengan tujuan, karena

\footnotetext{
${ }^{16}$ Departemen Pendidikan dan Kebudayaan, Kurikulum Sekolah Luar Biasa C, ttp, 1984, h. 37-38

${ }^{17}$ Marika Soebrata, Strategi Pembelajaran PLB, Surakarta : Universitas Sebelas Maret, 1997, h. 31-35
}

tujuan itulah yang menjadi tumpuan dan arah untuk memperhitungkan efektivitas suatu metode.

b. Keadaan Murid. Murid Merupakan unsur yang harus diperhitungkan, karena metode-metode yang hendak ditetapkan itu merupakan alat untuk menggerakkan mereka agar dapat mencerna/mempelajari bahan yang akan disampaikan.

c. Materi atau Bahan Pengajaran. Penguasaan bahan oleh guru hendaknya mengarah kepada sifat spesialitas atas ilmu atau kecakapan yang diajarkannya. Mengingat isi, sifat, dan luasnya, maka guru harus mampu menguaraikan ilmu atau kecakapan dan apa-apa yang akan diajarkan ke dalam bidang ilmu atau kecakapan yang bersangkutan.

d. Situasi

Yang dimaksud situasi disini adalah suasana belajar atau suasana kelas. Termasuk kedalam pengertian ini ialah suasana yang bersangkutpaut dengan keadaan murid-murid, seperti: kelelahan dan semangat belajar, keadaan cuaca, keadaan guru, misalnya sudah tidak segar lagi (lelah) atau tiba-tiba mendapat tekanan (stres), keadaan kelas yang bedekatan yang mungkin mengganggu atau terganggu karena penggunaan sesuatu metode.

e. Fasilitas

Fasilitas adalah segala sesuatu yang dapat mempermudah upaya atau memperlancar kerja dalam 
rangka mencapai suatu tujuan. Fasilitas dibagi menjadi dua yaitu:

1) Fasilitas yang bersifat fisik seperti: tempat dan perlengkapan belajar di kelas, alat-alat peraga pengajaran, buku pelajaran dan perpustakaan, tempat dan perlengkapan berbagai praktikum laboratorium atau keterampilan kesenian, keagamaan dan olahraga.

2) Fasilitas yang bersifat nonfisik, seperti: ruang gerak, waktu, kesempatan, biaya, dan berbagai aturan serta kebijaksanaan pimpinan sekolah.

\section{f. Guru}

Guru adalah pelaksanaan dan pengembangan program kegiatan belajar mengajar. Guru adalah pemilik pribadi keguruan, yaitu unik artinya tidak ada dua guru yang memiliki kepribadian keguruan yang sama. Jadi setiap guru memiliki pribadi keguruanya masing-masing yang tidak ada duanya.

Pribadi keguruan harus senantiasa dikembangkan untuk menyempurnakan penguasaan terhadap berbagai kopetesi dibidang keguruan yang kian terus berkembang.

Metode yang sama tidak akan membuat hasil yang sama ditangan guru yang berbeda-beda. Suatu metode yang dianggap 'kurang baik' oleh guru yang satu mungkin menjadi metode yang 'baik' digunakan oleh guru lain.

\section{Kelebihan dan Kelemahan Metode- Metode}

Tidak ada metode yang jelek atau metode yang baik. Dengan kata lain, kita tidak dapat mengatakan penuh kepastian bahwa metode inilah yang paling aktif dan metode itulah yang paling buruk karena hal itu amat tergantung pada banyak faktor.

Yang perlu diperhatikan adalah bagaimana guru dalam menetapkan metode gurulah yang mengetahui batasbatas kebaikan dan kelemahan metode yang akan dipergunakan, sehingga memungkinkan ia merumuskan kesimpulan mengenai hasil penilaian atau pencapaian tujuan dari putusannya itu. Hal itu dapat diketahui dari ciri-ciri atau sifat-sifat umum peranan dan manfaatnya, yang terdapat pada setiap metode, yang membedakan atara metode satu dengan yang lainnya. ${ }^{18}$

\section{Pengertian Guru}

Allah SWT berfirman dalam al-Qur'an QS. Al-Baqarah (2):31

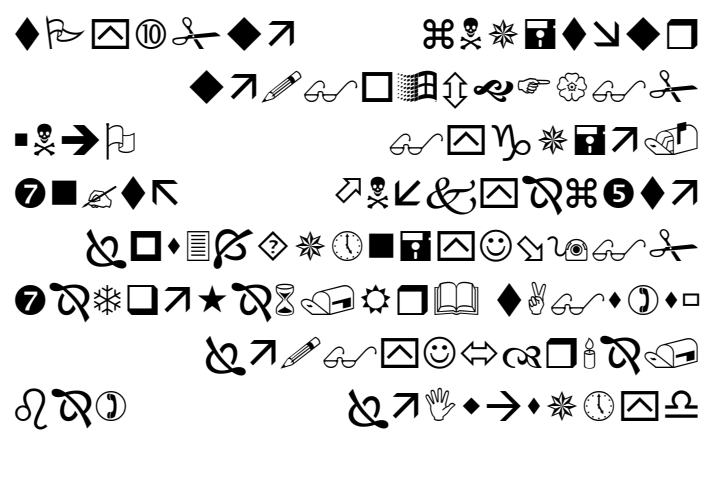

${ }^{18}$ Zakia Daradjat, Op. Cit, h. 137-143 


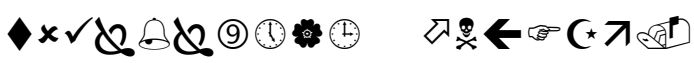
스료

Artinya: dan Dia mengajarkan kepada Adam nama-nama (benda-benda) seluruhnya, kemudian mengemukakannya kepada Para Malaikat lalu berfirman: "Sebutkanlah kepada-Ku nama benda-benda itu jika kamu mamang benar orang-orang yang benar". ${ }^{19}$

Dalam pengertian yang sederhana, guru adalah seorang yang memberikan ilmu pengetahuan kepada anak didik. Guru dalam masyarakat adalah orang yang melaksanakan dalam pendidikan di tempat-tempat tertentu tidak mesti di lembaga pendidikan formal, tetapi bisa juga di masjid, di mushola, di rumah dan sebagainya.

Pendidikan Agama Islam adalah seorang pendidik yang memberikan contoh dan panutan bagi para peserta didik dan memiliki kemampuan yang memadai untuk mengembangkan siswanya secara utuh untuk membimbing sampai tingkat dewasa sesuai dengan tuntunan Agama Islam.

a. Tujuan Pendidikan Agama Islam

Adapun tujuan pendidikan Agama Islam menurut Ahmadi adalah membentuk manusia susila yang berpribadi muslim yang beriman dan bertaqwa kepada Allah SWT, atau dengan kata lain yaitu menanamkan taqwa dan akhlaq serta menegakkan kebenaran untuk

${ }^{19}$ Departemen Agama RI, Op. Cit, h. 74 membentuk manusia yang berpribadi dan berbudi luhur sesuai dengan ajaran Agam Islam. $^{20}$

Mengenai tujuan pendidikan Agama Islam yang bersumber pada wahyu Allah yang berhubungan dengan tujuan akhir pendidikan Agama Islam yaitu membentuk pribadi muslim yang menghambakan diri atau beribadah kepada Allah SWT semata.

Berdasarkan firman Allah SWT dalam surat AzZariat ayat: 56

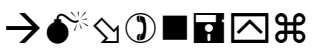 G $\rightarrow \square$

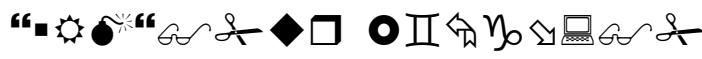

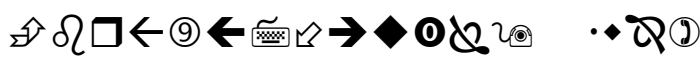 सिखे Artinya: dan aku tidak menciptakan jin dan manusia melainkan supaya mereka mengabdi kepada-Ku. (Qs. Az- Dzariyat: 56). ${ }^{21}$}

\section{Pengertian tuna Grahita}

Secara etimologi 'tuna' adalah rusak atau kurang, ${ }^{22}$ sedangkan 'grahita' adalah memahami atau mengerti. ${ }^{23}$ Tuna grahita adalah cacat pikiran, lemah

20 Abu Ahmadi, metode Khusus Mengajr Agama, Semarang, Toha Putra, 1976, h. 33

${ }^{21}$ Departemen Agama RI, Op. Cit, h. 417

22 Departemen Pendidikan Nasional, Op. Cit, h.1223

23 Departemen Pendidikan Nasional, Op. Cit, h.371 
daya tangkap atau idiot. $^{24}$ Tuna grahita merupakan kata lain dari retardasi mental (mental retaedasi).

Tuna berati merugi, grahita berati pikiran. Retardasi mental (mental retardation/mentally retarded) berati terbelakangan mental. ${ }^{25}$

Sedangkan menurut

Departemen Pendidikan Nasional

Tuna Grahita (retardasi mental) adalah anak yang secara nyata mengalami hambatan dan keterbelakangan perkembangan mental intelektual jauh di bawah rata-rata sedemikian rupa sehingga mengalami kesulitan dalam tugastugas akademik, komunikasi maupun sosial, dan karenanya membutuhkan bentuk pelayanan khusus. ${ }^{26}$

Sehubungan

dengan

pengertian di atas bahwa anak tuna grahita atau retardasi mental adalah anak secara nyata mengalami keterlambatan dan keterbelakangan perkembangan mental dan kecerdasannya di bawah rata-rata tetapi mereka juga berhak mendapatkan pendidikan khusus dari pemerintah.

Sebagaimana yang tertuang dalam Undang-Undang No. 20 tahun

24 Departemen Pendidikan Nasional, Op. Cit, h.1223

${ }^{25}$ Delphie, Bandi, “Pembelajaran Anak Tuna Grahita" dalam http://www.ditplb.or.id

/2006/index.php?menu=profile \&pro $=45$, (download: 09.00 wib, 25 Januari 2017)

26 Departemen Pendidikan Nasional, Alat identifikasi Anak Berkebutuhan Khusus, 2004, h. 16
2003 pasal 5 ayat 2 bahwa 'warga negara yang memiliki kelainan fisik, emosional, mental, intelektual, dan sosial berhak memperoleh pendidikan khusus'. ${ }^{27}$

Penderita tuna grahita atau cacat mental (mentally handicap) pada umumnya kelainan yang lebih dibandingakan dengan kelainan yang lain. Terutama kemampuan kognitifnya lambat, besar kecil tergntung intelegensinya yang dimiliki, sifat-sifatnya yang tampak adalah sebagai berikut:

a. Lambat belajar

b. Kemampuan mengatasi masalah kurang (problem solving)

c. Kurang bisa menghubungkan sebab akibat

d. Perbuatanya lucu

e. Mempunyai karakteristik kepala bayi secara signifikan lebih kecil dari kepala anak-anak lain pada usia dan jenis kelainan yang sama (mycrocepalie, macrocapalie, critinisme)

f. Kontrol motorik kurang

g. Kurang kemampuan dalam kordinasi

h. Mulut selalu mengangga

i. Dalam memahami suatu pengertian memiliki waktu yang lama

j. Kesulitan dalam sensoris

27 Undang-Undang sistem Pendidikan Nasional, Jakarta: Sinar Grafika, 2006, h. 5 
k. Hambatan dalam perkembangan bicara $^{28}$

American Asocistion on Mental Definicy (aamd) mendefinisikan tuna grahita sebagai kelainan:

a. Yang meliputi fungsi intelektual umum di bawah rata-rata (subaverage), yaitu IQ 84 ke bawah berdasarkan tes.

b. Yang muncul usia 16 tahun

c. Yang menunjukan hambatan dalam perilaku adaptif.

Sedangkan peningkatan menurut Japan League for Mentaly Retarded (sebagai berikut:

a. Fungsi intelektualnya lamban, yaitu IQ 70 ke bawah berdasarkan tes intelegensi buku

b. Kekurangan dalam perilaku adaptif

c. Terjadi pada masa perkembangan, yaitu antara masa konsepsi hingga usia 18 tahun. ${ }^{29}$

Ketuna grahitaan mengacu pada fungsi intelektual umum yang secara signifikan kekurangan dalam tingkah laku dan penyesuaian.

28 Abu Ahmad, dan Widodo Supriono, Psikologi Belajar, Jakarta:Rineka Cipta, 2004, h. 62

29 Delphie, Bandi, "Pembelajaran Anak Tuna Grahita" dalam http://www.ditplb.or.id/2006/index.php?m enu $=$ profile $\&$ pro $=45, \quad$ (download: 09.00 wib, 25 Januari 2017)
Semua itu berlangsung atau terjadi pada masa perkembangannya.

Tabel.

Tuna grahita berdasarkan klasifikasi berdasarkan mental:

\begin{tabular}{|c|c|c|c|c|}
\hline $\begin{array}{l}\mathrm{Na} \\
\mathrm{ma}\end{array}$ & $\begin{array}{l}\text { Um } \\
\text { ur } \\
(\mathrm{C} \\
\mathrm{A})\end{array}$ & IQ & $\begin{array}{c}\text { Umur } \\
\text { kecerd } \\
\text { asan } \\
\text { (M.A) }\end{array}$ & $\begin{array}{l}\text { Kemampu } \\
\text { an } \\
\text { mempelaja } \\
\text { ri dan } \\
\text { melakukan } \\
\text { tugas }\end{array}$ \\
\hline $\begin{array}{l}\mathrm{Si} \\
\mathrm{A}\end{array}$ & $\begin{array}{l}10 \\
\text { th }\end{array}$ & $\begin{array}{c}10 \\
0\end{array}$ & 10 th & $\begin{array}{l}\text { Ia tidak } \\
\text { kesulitan } \\
\text { mempelaja } \\
\text { ri dan } \\
\text { melakukan } \\
\text { tugas } \\
\text { seumurnya } \\
\text { karena } \\
\text { CA-nya } \\
\text { sama } \\
\text { dengan } \\
\text { MA-nya }\end{array}$ \\
\hline $\begin{array}{l}\mathrm{Si} \\
\mathrm{B}\end{array}$ & $\begin{array}{l}10 \\
\text { th }\end{array}$ & $\begin{array}{c}70 \\
- \\
55\end{array}$ & $\begin{array}{l}7 \text { th } \\
5,5 \text { th }\end{array}$ & $\begin{array}{l}\text { Ia dapat } \\
\text { mempelaja } \\
\text { ri materi } \\
\text { pembelajar } \\
\text { an/tugas } \\
\text { usia } 5,5 \\
\text { sampai } 7 \\
\text { tahun }\end{array}$ \\
\hline $\begin{array}{l}\mathrm{Si} \\
\mathrm{C}\end{array}$ & $\begin{array}{l}10 \\
\text { th }\end{array}$ & $\begin{array}{c}55 \\
- \\
40\end{array}$ & $\begin{array}{l}5,5 \text { th } \\
4 \text { th }\end{array}$ & $\begin{array}{l}\text { Ia dapat } \\
\text { mempelaja } \\
\text { ri materi } \\
\text { pembelajar } \\
\text { an/tugas } \\
\text { anak usia } 4 \\
\text { sampai } 2,5\end{array}$ \\
\hline
\end{tabular}




\begin{tabular}{|c|c|c|c|c|}
\hline & & & & tahun \\
\hline $\begin{array}{l}\mathrm{Si} \\
\mathrm{D}\end{array}$ & $\begin{array}{l}10 \\
\text { th }\end{array}$ & $\begin{array}{c}40 \\
- \\
25\end{array}$ & $\begin{array}{l}4 \text { th } \\
2,5 \text { th }\end{array}$ & $\begin{array}{l}\text { Ia dapat } \\
\text { mempelaja } \\
\text { ri materi } \\
\text { pembelajar } \\
\text { an/tugas } \\
\text { anak usia } 4 \\
\text { tahun } \\
\text { sampai } 2,5 \\
\text { tahun }\end{array}$ \\
\hline $\begin{array}{l}\mathrm{Si} \\
\mathrm{E}\end{array}$ & $\begin{array}{l}10 \\
\text { th }\end{array}$ & $\begin{array}{l}24 \\
\text { ke }\end{array}$ & 2,5 th & $\begin{array}{l}\text { Ia dapat } \\
\text { mempelaja } \\
\text { ri materi } \\
\text { pembelajar } \\
\text { an/tugas } \\
\text { usia 2,5 } \\
\text { tahun } \\
\text { kebawah }\end{array}$ \\
\hline
\end{tabular}

Seorang dikatakan normal (rata-rata) jika MA-nya sama atau hampir sama dengan CA-nya. Sedangkan apabila MA seorang jelas-jelas di atas CA-nya maka anak tersebut tergolong anak cerdas maka ia tergolong kecerdasan terbelakang, dan jika terbelakang dalam adaptasi perilaku dengan lingkungan maka ia disebut anak tuna grahita. ${ }^{30}$

\section{Efektivitas pelaksanaan metode pembelajaran guru pendidikan Agama Islam}

Metode mengajar memiliki peranan penting dalam suatu proses belajar mengajar termasuk dalam pendidikan Agama Islam, karena metode atau caraCit. h. 80

30 Departemen Pendidikan Nasional, Op. cara yang ditempuh guru menyampaikan materi pelajaran serta mengelola belajar siswa. Taraf efektivitas suatu proses belajar mengajar juga banyak dipengaruhi oleh jenis metode yang dipilih oleh guru dan bagaimana kemampuan guru dalam merealisasikannya.

Efektivitas pelaksanaan mengajar guru pendidikan Agama Islam di Sekolah Luar Biasa pada pelajaran Al-Qur'an dengan materi menirukan dan melafalkan Qur'an Surat Al-Ma'un, guru pendidikan Agama Islam menggunakan beberapa metode yaitu: metode drill, metode demonstrasi, metode eksperimen, dan metode resitasi (pekerjaan rumah). Metode ini merupakan metode yang paling efektif untuk mengajar pada anak tuna grahita sedang di Sekolah Luar Biasa Negeri Metro.

\section{Penafsiran dan Penjelasan}

Peneliti dalam penelitian ini mengadakan penafsiran dan penjelasan data tentang efektivitas pelaksanaan metode pembelajaran guru pendidikan Agama Islam pada anak tuna grahita sedang di Sekolah Luar Biasa Negeri Metro berdasarkan observasi dan wawancara terhadap guru pendidikan Agama Islam pada anak tuna grahita di Sekolah Luar Biasa Negeri Metro. Peneliti mengadakan pengamatan dan wawancara tentang materi mengajar dan metode mengajar yang dipergunakan.

a. Materi mengajar

Dalam pelaksanaan pembelajaran pendidikan Agama Islam seorang guru harus memiliki bahan pengajaran 
sebelum pengajaran tersebut di sampaikan atau dilaksanakan dalam proses belajar mengajar di sekolah. Bahan pengajaran ini berupa sumber materi pelajaran pendidikan Agama Islam diambil dari buku standar kompetensi dan kopetensi dasar Sekolah Luar Biasa Tuna Grahita Sedang Kelas IX Departemen Pendidikan Nasional tahun 2006, buku pelengkap dan penunjang lainnya.

b. Metode mengajar pendidikan Agama Islam di SLB Negeri Metro

Pelaksanaan metode mengajar pendidikan Agama Islam di Sekolah Luar Biasa:

1) Metode Drill, sebelum anak didik masuk kedalam ruangan dibiasakan agar berbaris di depan kelas dan mulai berhitung, ketika masuk anakanak juga dibiasakan bersalaman dengan guru, kemudian anak-anak berdo'a dipimpin oleh ketua kelas, kemudian guru menyampaikan materi Qur'an surat Al-Ma'un yang kemudian siswa memperhatikan dan guru tidak hanya sekali mengajarkannya, materi yang disampaikan satu pelajaran dapat berlaku hingga 4-5 kali pertemuan dan harus diulang-ulang sampai anak benar memahami. Apabila anak belum mengerti maka diulang-ulang kembali sampai anak pada saat itu mengerti. Dan dititik beratkan untuk membaca, mengenal huruf dan latihan terus-menerus.

Dari metode drill yang dilaksanakan di atas dengan teori yang diungkapkan oleh Darajat, bahwa metode drill adalah latihan bermaksud agar pengetahuan dan kecakapan tertentu dapat menjadi milik anak didik dan dikuasai sepenuhnya, sedangkan ulangan hanyalah untuk sekedar mengukur sejauh mana ia menyerap pengajaran tersebut. Jadi pelaksanaan metode drill yang dilaksanakan di Sekolah Luar Biasa sudah sesuai dengan yang diharapkan. Dan dari pengertian ini dapat diambil kelebihan dan kelemahan pelaksanaan metode mengajar di Sekolah Luar Biasa.

a) Kelebihan Metode Drill

- Anak didik mampu mengikuti pelajaran sedikit demi sedikit hingga peserta didik berhasil dalam pelajarannya.

- Dalam waktu yang relatif singkat, dapat diperoleh penguasaan dan keterampilan yang diharapkan.

- Akan tertanam pada setiap pribadi anak kebiasaan belajar secara rutin dan disiplin

b) Kelemahan Metode Drill

- Guru harus sabar dan telaten dalam mengajarkannya

- Bisa menghambat perkembangan daya inisiatif murid

- Kurang memperhatikan relevansinya dengan lingkungan 
- Membentuk kebiasaankebiasaan yang otomatis dan kaku

2) Metode Demonstrasi

Guru memperagakan atau mendemonstrasikan bacaan AlQur'an surat Al-Ma'un secara perlahan agar dapat diikuti dengan mudah oleh anak didik.

Metode demonstrasi merupakan salasatu teknik mengajar yang dilakukan oleh seorang guru atau orang lain yang ingin memperjelas suatu pengertian atau untuk memperlihatkan bagaimana melakukan sesuatu kepada anak didik. Adapun kelemahan dari pelaksanaan cara melafalkan QS. Al-Ma'un harus benar-benar jelas dan memakan waktu yang lama.

a) Kelebihan Metode Demonstrasi

- Dengan cara mengamati secara langsung siswa akan memiliki kesempatan untuk membandingkan antara teori dan kenyataan

- Proses pembelajaran akan lebih menarik, sebab siswa tidak hanya mendengar, tetapi juga melihat peristiwa yang terjadi

- Terjadinya verbalisme akan dapat dihindari, karena siswa disuruh langsung memperhatikan pelajaran yang dijelaskan

b) Kelemahan Metode Demonstrasi

- Memerlukan persiapan yang lebih matang, sebab tanpa persiapan yang memadai demonstrasi bisa gagal sehingga dapat menyebabkan metode ini tidak efektif lagi.

- Demonstrasi memerlukan peralatan, bahan-bahan, dan tempat yang memadai.

- Demonstrasi memerlukan kemampuan dan keterampilan guru yang khusus, sehingga guru dituntut untuk bekerja lebih professional

3) Metode Eksperimen

Setelah guru mendemonstrasikan kemudian siswa menirukan kembali bacaan QS. Al-Ma'un dan melafalkan sendiri satu persatu. Bagi yang mampu berbicara maka dengan hafalan kedepan, bagi yang tidak bisa mengucapkan maka dengan tertulis di ikuti suara dengan mereka.

Metode ini digunakan agar murid memperagakan kembali atau melakukan latihan sesuai dengan apa yang dicontohkan.

a) Kelebihan Metode Eksperimen

- Metode ini dapat membuat siswa lebih percaya atas kebenaran atau kesimpulan berdasarkan percobaannya sendiri dari pada hanya menerima kata guru atau buku.

- Hasil-hasil percobaan yang berharga yang ditemukan dari metode ini dapat memanfaatkan alam yang kaya ini untuk kemakmuran manusia. 
- Dapat melatih anak didik dalam bereksperimen

b) Kelemahan Metode Eksperimen

- Metode ini menuntut ketelitian, keuletan, dan ketabahan

- Hasil percobaan hanyalah usaha untuk mendekati kebenaran, bukanlah berupa kebenaran mutlak.

- Memerlukan waktu yang lama dalam menemukan bereksperimen

4) Metode Resitasi (pekerjaan rumah)

Setelah materi selesai maka anak diberi tugas di rumah untuk menghafal surat Al-Maun supaya anak dapat berlatih di rumah.

Metode ini digunakan untuk mencari informasi atau melatih daya ingatnya, di luar jam pelajaran. Kelemahannya, siswa sering lupa apabila diberi tugas rumah dan guru sering mengalami kesukaran dalam pemberian tugas yang sesuai dengan kemampuan yang di miliki anak didik, kelebihannya, mengisi waktu luang di rumah dan memperkuat daya ingatnya.

a) Kelebihan Metode Resitasi (pekerjaan rumah)

- Mendidik untuk lebih aktif belajar.

- Menumbuhkan keberanian siswa untuk mengambil ini siatif sendiri, dan mampu bertanggung jawab terhadap apa yang telah ia pilih.
- Hasil dari belajar sendiri akan lebih mudah dan lebih lama diingat oleh siswa

b) Kelemahan Metode Resitasi (pekerjaan rumah)

- Siswa dapat mencontek pekerjaan rumah dari temannya.

- Pekerjaan siswa dapat dikerjakan oleh orang lain.

- Guru sulit mengetahui tingkatan kecerdasan siswa

\section{Keberhasilan metode pembelajaran dalam meningkatkan pemahaman pendidikan Agama Islam pada anak tuna grahita kelas IX SMPLB/C di SLB Negeri Metro}

Disetiap sekolah umum maupun sekolah khusus tentunya tingkat keberhasilan peserta didik sudah menjadi hal yang wajib, itu juga berlaku untuk Sekolah Luar Biasa Negeri Metro. Meski tingkat keberhasilan itu tidak seperti sekolah-sekolah umum, tetapi anak mulai berkembang baik, anak dapat menghafal sedikit surat-surat pendek, membawa iqro dari rumah yang diajarkan, itu juga sudah merupakan hasil yang baik untuk anak-anak yang berkebutuhan khusus, anak juga merasa senang saat melakukan pembelajaran dengan metode-metode yang diterapkan, itu juga merupakan hasil yang baik. Hal ini sesuai dengan apa yang di sampaikan oleh Ibu Umi Sarimanah yaitu:

"Untuk tingkat keberhasilan mas sudah ada perkembangan dan kemajuan dibanding dulu waktu awal-awal masuk 
sini. Anak bisa bermanfat untuk dirinya sendiri seperti terbiasa melaksanakan sholat ya, biarpun hanya mengetahui gerakan-gerakannya saja, menghafal surat-surat pendek, kebiasaan membawa iqro, ramah tamah serta tidak mengganggu orang lain sudah cukup baik mas".

Hasil pembelajaran Agama Islam merupakan barometer bagi baik atau buruknya pembelajaran yang telah dilakukan. Apakah sudah berjalan sesuai dengan tujuan pembelajaran yang telah ditetapkan atau belum. Indikasi keberhasilan dari proses, pembelajaran Agama Islam di SLB Negeri Metro antara lain: kebiasaan buruk siswa sedikit demi sedikit sudah berkurang, siswa dapat menunjukan perilaku yang baik dalam kehidupan sehari-hari, baik sesama guru, teman, dan orang tua, siswa dapat membawa iqro dan bisa membaca iqro dan dapat menghafal surat-surat pendek.

Dari keterangan di atas dapat disimpulkan bahwa tingkat keberhasilan pemahaman pada anak tuna grahita kelas IX SMPLB/C di SLB Negeri Metro mengalami perkembangan yang baik, artinya ada beberapa perilaku awalnya belum bisa dan masih perlu arahan dari guru pembimbing untuk membawa iqro dan menghafalkan surat-surat pendek sekarang sudah terbiasa melakukan sendiri namun masih dalam monitor guru pendamping dan orang tua, dan tidak mengganggu orang serta ramah terhadap orang lain.

\section{KESIMPULAN}

Berdaaarkan hasil pengolahan datadata yang berhasil di kumpulkan dalam penelitian, maka dapat di simpulkan bahwa:

1. Efektivitas pelaksanaan metode mengajar pendidikan Agama Islam guna peningkatan pemahaman pada anak tuna grahita sedang kelas IX SMPLB/C di Sekolah Luar Biasa Negeri Metro adalah sebagai berikut:

a. Pelaksanaan metode drill yaitu guru pendidikan Agama Islam memberikan latihan secara terus menerus dan dengan berulangulang kepad anak tuna grahita sedang sehingga anak tersebut memiliki kecakapan dan mengukur sejauh mana anak menyerap pelajaran.

b. Pelaksanaan metode demonstrasi yaitu guru memperagakan materi QS. Al- Ma'un secara perlahan agar dapa diikuti dengan mudah oleh anak didik.

c. pelaksanaan metode eksperimen yaitu setelah guru mendemonstrasikan materi pelajaran Agama Islam yakni QS. Al-ma'un kemudian anak didik menirukan kembali materi yang disampaikan.

d. Dan metode resitasi yaitu guru memberikan tugas atau pekerjaan rumah kepada anak didik untuk memperkuat daya ingatnya.

2. Faktor penghambat dalam pembelajaran dalam pembelajaran pendidikan Agama Islam pada anak 
tuna grahita adalah penyerapan anak dalam pelajaran sabgat lambat.

Faktor pendukung adalah di tuunjang dengan alat peraga lain yang bersifat variat

\section{DAFTAR PUSTAKA}

Ahmadi, Abu, Metode Khusus Mengajar Agama, Semarang, Toha Putra, 1976 dan Supriyono, Widodo,

Psikologi Belajar, Jakarta, Rineka Cipta, 2004

Amin, Muhammad, Ortopedagogik Anak Tuna Grahita, Departemen Pendidikan dan Kebudayaan, 1998 , Metode Penelitian,

Jakarta, Ghalia Indonesia, 1998

Andayani, Dian dan Majid Abdul, Pendidikan Agama Islam Berbasis Kompetensi, Bandung, PT. Remaja Rosdakarya, 2004

Arifin, H.M. Ilmu Pendidikan Islam, (tinjauan teoritis dan praktis berdasarkan pendekatan interdisiplinier), Jakarta, PT. Bumi Aksara, 2003

Arikunto, Suharsimi, Prosedur Penelitian Suatu Pendekatan Praktek. Jakarta, Rineka Cipta, 2002 , Prosedur Penelitian

Suatu Pendekatan Praktek, Yogyakarta, Rineka

Cipta, edisi revisi IV, 1997

Bungin, Burhan, Metode Penelitian Sosial, Surabaya, Airlangga University Peress, 2002
B. Uno Hamzah, Model-Model Pembelajaran, Jakarta, Bumi Aksara, 2007

Daradjat, Zakiah, dkk, Metode Pengajaran Agama Islam, Jakarta, Bumi Aksara, 1996

Metode Khusus

Pengajaran Agama Islam, Jakarta, Bumi Aksara,

1995

Departemen Agama, Al-Qur'an dan Terjemah. Bandung, Diponegoro, 2006

Pedoman Umum

Pendidikan Agama Islam di Sekolah Umum dan

Sekolah Luar Biasa, Direktorat Jendral Kelembagaan Agama Islam, 2003

Departemen Pendidikan Nasional, Standar Kompetensi dan Kompetensi Dasar Sekolah Luar Biasa Tuna Grahita Sedang (SDLB/C1), Badan Standar Nasional, 2006

Departemen Pendidikan dan Kebudayaan, Kurikulum Sekolah Luar Biasa C, 1984

Direktorat Jendral Pendidikan Nasional, Alat Identifikasi Anak Berkebutuhan Khusus, ttp, 2004

Bahasa Indonesia, Jakarta, Balai Pustaka, 2006

Dimyati dan Mudjiono, Belajar dan Pembelajaran, Jakarta, Departemen Pendidikan dan Kebudayaan bekerjasama dengan Rineka, 1999 
Direktorat Pembinaan Sekolah Luar

Biasa, Model Pembelajaran

Pendidikan Khusus, ttp, 2007

Hawi, Akmal, Kompetensi Guru

Pendidikan Agama Islam, Jakarta,

Raja Grafindo Persada, 2013

Kadir, Abdul, dkk, Dasar-Dasar

Pendidikan, Jakarta, Kencana

Prenada Media Group, 2012

Karwono, Belajar dan Pembelajaran. Jakarta, Raja Grafindo Persada, 2012

Koentjaraningrat, Metode-metode

Penelitian Masyarakat, Jakarta, PT. Gramedia, 1986

Majid, Abdul, Perencanaan

Pembelajaran, Bandung, PT

Remaja Rosda Karya, 2008

Meloeng, Lexy, Metodologi Penelitian

Kualitatif, Bandung, PT. Remaja

Rosda Karya, 2006

Miarso, Yusufhadi, Menyemai Benih

Teknologi Pendidikan, Jakarta, Pranada Media, 2004

Muhibbin Syah, Psikologi Belajar, Edisi

I, cet ke-6, Jakarta, PT Raja Grafindo Persada, 2007

NK, Roestiyah, Didaktik Metodik,

Jakarta, Bumi Aksara, 1992

Ramayulis, Ilmu Pendidikan Islam, Jakarta, Kalam Mulia, 2002

Sadirman, Interaksi dan Motivasi Belajar Mengajar, Cet ke-18, Jakarta, PT Raja Grafindo Persada, 2010

Sarbi, Ahmad, Strategi Belajar Mengajar Micro Teaching, Jakarta, Quantum Teaching, 2005
Sarbi, Alisuf, M, Ilmu Pendidikan, Jakarta, CV Pedoman Ilmu Jaya, 1999

Soebrata, Marika, Strategi Pembelajaran $P L B, \quad$ Surakarta, Universitas Sebelas Maret, 1997

Sugiyono, Memahami Penelitian Kualitatif, Bandung, Alfabeta, Cet. IX, 2014

Surahman, Winarno, Penelitian Ilmiah, Bandung, Tarsito, 1990

Tafsir, Ahmad, Ilmu Pendidikan dalam Perspektif Islam, Bandung, Remaja Rosdakarya, 2001

Wahab, Aziz, Abdul, Metode dan ModelModel Pembelajaran, Bandung, Alfabeta, 2009

Zuhairini dan Abd. Ghofir, Metodologi Pembelajaran Pendidikan Agama Islam. Malang, UNM, 2004

Muslimah, Tips Dari Rasullulah Bagi Penghafal Al-Qur'an https://muslimah.or.id/6390-tipsdari-rasulullah-bagi-penghafal-alquran.html 